\title{
Penerapan Prinsip Akuntabilitas Dan Transparansi Dalam Pengelolaan Anggaran Pendapatan Dan Belanja Desa
}

\author{
Nani Anggriani ${ }^{1}$ \\ 1 Universitas Muhammadiyah Sukabumi \\ nanianggriani1510@gmail.com \\ Idang Nurodin ${ }^{2}$ \\ ${ }^{2}$ Universitas Muhammadiyah Sukabumi \\ Deni Iskandar ${ }^{3}$ \\ 3Universitas Muhammadiyah Sukabumi
}

\begin{abstract}
ABSTRAK - Penelitian ini bertujuan untuk mengetahui : 1) Penerapan Prinsip Akuntabilitas dalam Pengelolaan Anggaran Pendapatan dan Belanja Desa (APBDes). 2) Penerapan Prinsip Transparansi dalam Pengelolaan Anggaran Pendapatan dan Belanja Desa (APBDes). 3) Faktor pendukung dan Penghambat dalam penerapan prinsip Akuntabilitas dan Transparansi dalam Pengelolaan Anggaran Pendapatan dan Belanja Desa (APBDes). Variabel terdiri dari Akuntabilitas dan Transparansi sebagai variabel independen, variabel Pengelolaan Anggaran Pendapatan dan Belanja Desa (APBDes) sebagai variabel independen. Metode penelitian yang digunakan adalah metode kualitatif dengan pendekatan deskriptif. Penelitian ini dilakukan dengan menggunakan teknik observasi dan wawancara dengan pihak-pihak yang terlibat dalam pengelolaan Anggaran Pendapatan dan Belanja Desa (APBDes). Hasil deskripsi dapat dilihat dari perbandingan Peraturan Menteri dalam Negeri Nomor 113 Tahun 2014 dengan hasil realisasi di lapangan. Pengelolaan Anggaran Pendapatan dan Belanja Desa dari tahap Perencanaan, Pelaksanaan, Penatausahaan, Pelaporan dan Pertanggungjawaban secara garis besar sudah sesuai dengan Peraturan Menteri dalam Negeri Nomor 113 Tahun 2014 tentang Pengelolaan Keuangan, meskipun terdapat beberapa hal dalam Perencanaan, Pelaksanaan, Penatausahaan, Pelaporan dan Pertanggungjawaban yang masih belum sesuai dikarenakan sumber daya manusia yang kurang mendukung.
\end{abstract}

Kata Kunci : Akuntabilitas, Transparansi, Pengelolaan Anggaran Pendapatan dan Belanja Desa

ABSTRACT - This research was aimed to find out : 1) Application of Accountability Principles in Management of Income and Village Budget. 2) Application of Transparenci Principles in Management of Income and Village Budget. 3) Supporting and Inhibiting Factors in applying the principles of Accountability and Transparency in the Management of income and Village Budgets. The variabel of this reasech was consisted of Accountability, Tranparency as independent varable and management of income and Village badgets as dependent variable. The research methode used is qualitative method with descriptive approach. This research was conducted using observation and interview techniques with the parties involved in managing the income 
and Village Budget. The results of the description can be seen from the comparison of Minister of Home Affairs Regulation No. 113 of 2014 with the results of realization in the field. Management of the income and Village Budget from the Planning, Implementation, Administration, Reporting and Accountability phases is broadly in accordance with the Minister of Home Affairs Regulation No. 113 of 2014 concerning Financial Management, although there are several things in Planning, Implementation, Administration, Reporting and Accountability still not suitable because human resources are less supportive.

Keywords: Accountability, Transparency and management of income and village budgets

\section{PENDAHULUAN}

Prinsip akuntabilitas dan transparansi merupakan prinsip yang harus diterapkan dalam pengelolaan dana yang diterima oleh Desa. Dana Desa yang diterima oleh desa dari pemerintah yang jumlahnya cukup besar ini perlu dikelola secara efisien dan efektif. Hal ini untuk menghindari terjadi tindakan kecurangan (Fraud) dalam pengelolaannya.

Adapun permasalahan yang terjadi pada Desa Citanglar, Desa Jagamukti dan Desa Kademangan yaitu kurangnya keterbukaan kepada masyarakat. Pelaksanaan musyawarah terkait Anggaran Pendapatan dan Belanja Desa (APBDes) belum terlaksana secara maksimal, padahal tanpa musyawarah Desa, akses masyarakat dalam memperoleh informasi pengelolaan dana desa menjadi tertutup. Hakikatnya Musyawarah Desa ini adalah amanah dalam implementasi Undang-Undang Nomor 6 Tahun 2014.

Ketidakterbukaan dalam pengelolaan dana desa ini, salah satunya tidak adanya musyawarah desa yang diamanatkan oleh UU ini, mendorong penulis mencermati dan meneliti terkait APBDes dikelola dengan akuntabel dan transparan. Penelitian ini bertujuan untuk: 1) Mengetahui bagaimana anggaran pendapatan dan belanja desa dikelola dengan menggunakan prinsip akuntabilitas. 2) Mengetahui bagaimana anggaran pendapatan dan belanja desa dikelola dengan prinsip transparansi. 3) Mengetahui faktor pendukung dan penghambat dalam pengelolaan anggaran pendapatan dan belanja desa dengan menggunakan prinsip akuntabilitas dan transparansi . Maka peneliti tertarik untuk melakukan penelitian yang dituangkan dalam judul "Penerapan Prinsip Akuntabilitas dan Transparansi dalam Pengelolaan Anggaran Pendapatan dan Belanja Desa (APBDes)"

\section{LANDASAN TEORI}

\section{Akuntabilitas}

Asas dan prinsip yang menentukan pertanggungjawaban pengelolaan keuangan desa agar dapat dipertanggungjawabkan sesuai undang-undang kepada masyarakat adalah prinsip akuntabilitas. (Sholeh : 2015).

Lebih lanjut, Akuntabilitas merupakan kemampuan otoritas yang lebih tinggi dalam memberikan jawaban kepada masyarakat luas atas tindakan seseorang/sekelompok orang dalam suatu organisasi. (Sholeh : 2015).

Berdasarkan hal tersebut, akuntabilitas dapat dipahami sebagai 
bentuk pertanggungjawaban lembaga yang diberi wewenang dalam pengelolaan sumber daya Publik.

\section{Transparansi}

Transparansi merupakan prinsip keterbukaan diperolehnya informasi yang benar dan jujur dalam pengelolaan keuangan desa dengan tetap tidak diabaikannya perlindungan pada hak pribadi dan golongan. (Sholeh : 2015).

Transparansi bagian dari penyedia informasi tentang pemerintah bagi publik dan dijaminnya kemudahan dalam memperoleh informasi-informasi yang akurat dan memadai. (Dwiyanto :2015)

Berdasarkan pengertian diatas dapat dipahami Transparansi merupakan diperolehnya informasiinformasi yang terbuka mengenai informasi keuangan maupun kebijakankebijakan yang dilakukan pemerintah serta menjamin diperolehnya akses informasi bagi masyarakat.

\section{Pengelolaan Anggaran Pendapatan dan Belanja Desa (APBDes)}

Cakupan pengelolaan APBDesa dimulai dari tahap pelaksanaan, penatausahaan dan terakhir tahap pertanggungjawaban. (Sholeh:2015) APBDes ini hakikatnya merupakan rencana tahunan pemerintah Desa.

$$
\text { Adapun }
$$

penelitiannya sebelumnya dilakukan oleh Iqsan (2016) melakukan penelitian dengan judul "Transparansi pemerintah desa dalam penyusunan Anggaran Pendapatan dan belanja Desa (APBDes) di Desa Long Nah Kecamatan Muara Ancalong Kabupaten Kutai Timur " diperoleh hasil bahwa transparansi pemerintah desa terlaksana dengan baik. Soeharso (2017) melakukan penelitian yang berjudul “ Akuntabilitas Pemerintah Desa dalam Pengelolaan Anggaran Pendapatan dan Belanja Desa (APBDes) di Desan Argorejo dan Desa Argodadi Kecamatan Sedayu Kabupaten Bantul" diperoleh hasil bahwa akuntabilitas pemerintahan desa sudah mulai dilakukan secara bertahap.

Pembinaan lebih lanjut dalam administrasi sangatlah diperlukan, mengingat masih ditemukan keterlambatan dalam pelaporan keuangan desa. Nafidah dan Anisa (2017) juga melakukan penelitian "akuntabilitas pengelolaan keuangan Desa di Kabupaten Jombang". Penelitian ini memberikan gambaran bahwa akuntabilitas dapat dicapai dalam pengelolaan keuangan desa.

\section{METODE PENELITIAN}

Metode yang digunakan peneliti dalam menganalisis, menggunakan metode kualitatif. Pendekatan metode kualitatif yang diambil merupakan pendekatan deskriptif. Pendekatan deskriptif ini, data yang diamati berbentuk kata-kata dan gambar, tidak menggunakan data berbentuk angka. Metode kualitatif deskriptif ini diyakini dapat menganalisis penerapan akuntabilitas dan transparansi dalam Pengelolaan Anggaran Pendapatan dan Belanja Desa pada Desa Citanglar, Desa Jagamukti dan Desa Kademangan.

Informan dalam penelitian ini adalah terdiri dari:

1. Kepala Desa

2. BPD

3. Masyarakat Desa

\section{HASIL PENELITIAN}

Pengelolaan APBDES, khususnya di Desa Citanglar, Desa Jagamukti dan Desa Kademangan Kecamatan Surade dimulai dari tahap 
perencanaan, pelaksanaan, penatausahaan, pelaporan dan pertanggungjawaban.

1. Akuntabilitas Pengelolaan APBDes

a. Tahap perencanaan

1. Perencanaan Desa Citanglar Perencanaan pengelolaan Anggaran Pendapatan dan Belanja Desa (APBDes) di Des Citanglar dimulai dari dusun yang disebut dengan Musyawarah Dusun (Musdus) yang dihadiri oleh kepala desa, perangkat desa, Badan Permusyawaratan Desa (BPD), Tokoh perempuan dan Tokoh Masyarakat untuk membahas berbagai perencanaan pembangunan desa yang dibutuhkan Masyarakat sesuai dengan kondisi dan potensi Desa dan dapat didanai oleh APBDes yang selanjutnya akan dibahas dalam Musyawarah Desa (Musdes) yang dihadiri oleh BPD, Tokoh perempuan, para ulama, Tokoh Masyarakat, Karang Taruna dan lembagalembaga yang ada di Desa Citanglar untuk menyusun Rencana Kerja Pemerintah Desa (RKPDes).

2. Perencanaan Desa Jagamukti Perencanaan pengelolaan Anggaran Pendapatan dan Belanja Desa (APBDes) di Desa Jagamukti dimulai dari tahapan dusun yang disebut dengan Musyawarah Dusun (Musdus) yang dihadiri oleh kepala desa, perangkat desa, Badan Permusyawaratan Desa (BPD), Tokoh perempuan dan Tokoh Masyarakat untuk membahas berbagai perencanaan pembangunan desa yang dibutuhkan
Masyarakat sesuai dengan kondisi dan potensi Desa dan dapat didanai oleh APBDes yang selanjutnya akan dibahas dalam Musyawarah Desa (Musdes) yang dihadiri oleh BPD, Tokoh perempuan, para ulama, Tokoh Masyarakat, Karang Taruna dan lembagalembaga yang ada di Desa Jagamukti untuk menyusun Rencana Kerja Pemerintah Desa (RKPDes).

3. Perencanaan

Desa Kademangan

Perencanaan pengelolaan Anggaran Pendapatan dan Belanja Desa (APBDes) di Desa Kademangan dimulai dari dusun yang disebut dengan Musyawarah Dusun (Musdus) yang dihadiri oleh kepala desa, perangkat desa, Badan Permusyawaratan Desa (BPD), Tokoh perempuan dan Tokoh Masyarakat untuk membahas berbagai perencanaan pembangunan desa yang dibutuhkan Masyarakat sesuai dengan kondisi dan potensi Desa dan dapat didanai oleh APBDes yang selanjutnya akan dibahas dalam Musyawarah Desa (Musdes) yang dihadiri oleh BPD, Tokoh perempuan, para ulama, Tokoh Masyarakat, Karang Taruna dan lembagalembaga yang ada di Desa Kademangan untuk menyusun Rencana Kerja Pemerintah Desa (RKPDes).

b. Pelaksanaan

1. Pelaksanaan Desa Citanglar Pelaksanaan pembiayaan program yang dilakukan Desa Citanglar yang dananya 
bersumber dari Anggaran

Pendapatan dan Belanja

Desa (APBDes) sepenuhnya

dilaksanakan oleh tim

pelaksana kegiatan (TPK)

desa yang ada di Desa

Citanglar sesuai dengan

ketentuan pemerintah

kabupaten Sukabumi. dan untuk menerapkan prinsip transparansi kepada masyarakat perangkat desa mensosialisasikan segala kegiatan pembangunan beserta anggaran yang dianggarkan dalam berbagai acara yang diadakan oleh masyarakat maupun perangkat desa Citanglar, seperti dalam acara Maulid Nabi, Isra Mi'raj ataupun acara lainnya yang dihadiri oleh masyarakat desa Citanglar. Dengan demikian Masyarakat mengetahui dan penerapan prinsip Akuntabilitas dan Transparansi ter jalankan dengan Baik.

2. Pelaksanaan Desa Jagamukti Pelaksanaan kegiatankegiatan pemberdayaan Masyarakat bersumber dari Anggaran Pendapatan dan Belanja Desa (APBDes) dilaksanakan oleh tim pelaksana desa yang ada di Desa Jagamukti. Kepala Desa melakukan Musyawarah Dusun merencanakan APBDes untuk tahun berjalan setelah dititik dusun selesai maka dilaksanakan musyawarah desa dengan melibatkan perangkat Desa, BPD, RT, RW dan lembaga masyarakat lainnya.
3. Pelaksanaan

Kademangan

Dalam

pengelolaan

pelaksanaan

Pengelolaan Anggaran

Pendapatan dan Belanja

Desa, sangat diperlukan akuntabilitas dan transparansi dalam pengelolaannya, dari segi akuntabilitas pengelolaan APBDes, desa Kademangan Melakukan setiap tahapantahapan Pengelolaannya sesuai dengan Rencana Anggaran Biaya (RAB), adapun dari sisi Transparansinya Desa Kademangan menyampaikan setiap kegiatan yang dilakukan dari mulai anggaran sampai waktu pelaksanaannya kepada masyarakat, sehingga asasasas akuntabilitas dan transparansinya terjalankan dengan baik sesuai dengan undang-undang yang berlaku tentang Keuangan Desa.

c. Penatausahaan

1. Penatausahaan Desa Citanglar Tahap penatausahaan Anggaran Pendapatan dan Belanja Desa (APBDes) di Desa citanglar dilakukan oleh Bendahara Desa. Bendahara Desa wajib melakukan pencatatan terhadap seluruh transaksi yang berupa penerimaan dan pengeluaran kas dengan menggunakan sistem keuangan desa (Siskudes) Bendahara wajib mempertanggungjawabkan melalui laporan pertanggungjawaban. Laporan pertanggungjawaban 
disampaikan oleh bendahara Desa Citanglar setiap akhir bulan kepada Kepala Desa.

2. Penatausahaan

Desa Jagamukti

Pada Desa Jagamukti, tahapan penatausahaan pengelolaan Anggaran Pendapatan dan Belanja Desa (APBDes) dilakukan oleh bendahara Desa. Bendahara desa melakukan pencatatan atas transaksi baik pemasukan maupun pengeluaran Kas dengan menggunakan sistem keuangan desa (Siskudes) Bendahara Desa Jagamukti melakukan setiap pencatatan harus sistematis dan kronologis atas transaksi yang terjadi. Bendahara desa Jagamukti mempertanggungjawabkan uang melali laporan pertanggungjawaban yang disampaikan setiap akhir bulan kepada Kepala Desa.

3. Penatausahaan Desa Kademangan

Tahapan penatausahaan pengelolaan Anggaran Pendapatan dan Belanja Desa (APBDes) di Desa Kademangan dilakukan oleh bendahara Desa. Bendahara desa melakukan pencatatan atas transaksi-transaksi yang terjadi secara sistematis dengan menggunakan sistem keuangan desa (Siskudes) Selain itu juga Bendahara Desa Jagamukti melakukan laporan pertanggungjawaban kepada kepala Desa setiap akhir bulan.

\section{d. Pelaporan}

\section{Pelaporan Desa Citanglar}

Pelaporan pengelolaan Anggaran Pendapatan dan Belanja Desa (APBDes) dilaksanakan setiap pencairan Dana Desa sebanyak tiga tahap, dimana setiap tahap harus dibuatkan laporan pertanggungjawaban sebagai syarat untuk pengajuan Anggaran Pendapatan dan Belanja Desa (APBDes) tahap selanjutnya. Selain itu juga pelaporan pengelolaan Anggaran Pendapatan dan Belanja Desa (APBDes) dilakukan untuk mengetahui seperti apa pengelolaan Anggaran Pendapatan dan Belanja Desa (APBDes) yang dilakukan oleh perangkat Desa Citanglar tersebut, dan laporan pertanggungjawaban

disampaikan oleh kepala Desa Citanglar kepada Pemerintah Kabupaten Sukabumi melalui Camat.

\section{Pelaporan Desa Jagamukti}

Tahapan pelaporan dilaksanakan di Desa Jagamukti sebagai bentuk pertanggungjawaban Desa Jagamukti terhadap dana Desa yang telah diterima setelah dikelola dan dipakai untuk kegiatan pemberdayaan Masyarakat Desa. Selain itu bentuk pelaporan juga dilaksanakan untuk mengetahui proses pengelolaan Anggaran Pendapatan dan Belanja Desa (APBDes) yang ada di Desa Jagamukti. Pelaporan Anggaran Pendapatan dan Belanja Desa dilakukan dua tahap, yaitu laporan realisasi APBDes semester pertama 
pada bulan juli tahun berjalan dan laporan realisasi APBDes semester akhir tahun pada bulan januari tahun berikutnya.

3. Pelaporan Desa Kademangan Pelaporan pertanggungjawaban

$\begin{array}{lr}\text { Pengelolaan Anggaran } \\ \text { Pendapatan dana } & \begin{array}{r}\text { Belanja } \\ \text { Desa (APBDes) }\end{array} \\ \text { Kademangan } & \text { dilakukan } \\ \text { sebagai } & \text { bentuk }\end{array}$
pertanggungjawaban terhadap Dana Desa yang diterima oleh Desa Kademangan setelah dikelola dan digunakan untuk kepentingan masyarakat Desa Kademangan seperti pembuatan jalan, pendanaan lembaga kesehatan dan lainlain. Selain itu juga pelaporan Anggaran pendapatan dan belanja Desa (APBDes) dilaksanakan untun mengetahui perkembangan proses pengelolaan APBDes yang pelaporannya terdiri dari dua tahap yaitu laporan realisasi APBDes semester pertama pada bulan Juli tahun berjalan dan laporan realisasi semester akhir pada bulan Januari tahun berikutnya.

e. Pertanggungjawaban

1. Pertanggungjawaban Desa Citanglar

Pertanggungjawaban kepada masyarakat dilakukan oleh perangkat desa Citanglar dengan memberikan informasiinformasi mengenai pengelolaan Anggaran Pendapatan dan Belanja Desa (APBDes) dan programprogram yang dilaksanakan Desa pada perkumpulan masyarakat yang rutin dilaksanakan. Selain itu juga perangkat desa memasang papan nama kegiatan mengenai kegiatan yang dilaksanakan juga anggaran yang dikeluarkan dalam kegiatan tersebut sehingga masyarakat mengetahui kegiatan desa yang sedang dilakukan. Hal tersebut dapat membimbing masyarakat untuk ikut aktif dan berpartisipasi dan memberikan masukan terkait pengelolaan Anggaran Pendapatan dan Belanja Desa (APBDes) yang dilakukan sehingga asas transparansi dalam pengelolaan APBDes terlaksana.

2. Pertanggungjawaban Desa Jagamukti

Anggaran Pendapatan dan Belanja Desa (APBDes) adalah sumber pendapatan desa yang sangan membantu pemerintah desa dalam menjalankan pemerintahannya dan melakukan pembangunan desa untuk menyejahterakan masyarakat melalui programprogram pemberdayaan masyarakat seperti pembangunan jalan, kegiatan pengelolaan Poskesdes, kegiatan fasilitasi keluarga Berencana dan lain-lain yang harus di kelola berdasarkan asas akuntabilitas dan transparansi kepada masyarakat desa Jagamukti maupun kepada pemerintahan diatasnya yaitu kepada bupati atau Walikota melalui kecamatan. 
3. Pertanggungjawaban Desa Kademangan

Pertanggungjawaban kepada masyarakat dilakukan oleh kepala desa dan perangkat desa dengan memberikan informasi-informasi mengenai program pemberdayaan masyarakat yang di danai oleh APBDes yang sedang dilaksanakan oleh Desa Kademangan pada kegiatankegiatan perkumpulan masyarakat seperti isra mi'raj, maulid nabi ataupun acara pengajian mingguan Desa sehingga masyarakat mengetahui dan dengan demikian dari kegiatan tersebut dapat mengajak masyarakat untuk ikut berpartisipasi dalam kegiatan-kegiatan

pemberdayaan Masyarakat di Desa Kademangan sehingga akan tercipta pengelolaan Anggaran Pendapatan dan Belanja Desa (APBDes) yang akuntabel dan transparan.

2. Transparansi Pengelolaan APBDes a. Transparansi Desa Citanglar

Penerapan

prinsip transparansi pada pengelolaan Anggaran Pendapatan dan Belanja Desa (APBDes) yang dilakukan perangkat Desa Citanglar dapat dilihat dari musyawarah Dusun (Musdus) dan Musyawarah Desa (Musdes) yang dilakukan di Desa Citanglar yang mengundak sejumlah perwakilan masyarakat seperti perwakilan perempuan, Karang taruna dan masih banyak lagi. Dalam Musyawarah Dusun (Musdus) dan Musyawarah Desa (Musdes) tersebut setiap masukan ataupun pendapat dari masyarakat di tampung dan dicatat untuk dibentuk program kerja yang akan masuk ke Anggaran Pendapatan dan Belanja Desa (APBdes).

Pelaksanaan pembangunan Desa yang didanai Anggaran Pendapatan dan Belanja Desa (APBdes) demi terlaksananya penerapan prinsip Transparansi dalam pengelolaannya perangkat desa memasang papan kegiatan sehingga masyarakat mengetahui jumlah anggaran yang digunakan dalam kegiatan tersebut. Selain itu juga dilakukannya sosialisasi dengan cara menyampaikannya dalam kegiatan-kegiatan perkumpulan masyarakat seperti isra mi'raj dan maulid nabi ataupun kegiatan pengajian mingguan. Selain itu juga dilakukannya pengawasan dengan terjun langsung ke lapangan pada saat kegiatan oleh Badan Permusyawatan Desa (BPD) dan Tim Pendamping Kecamatan serta Tokoh masyarakat untuk evaluasi kegiatan pembangunan.

Berdasarkan penelitian yang dilakukan di Desa Citanglar dapat diketahui bahwa aksesibilitas masyarakat terhadap data-data yang bersifat keuangan seperti Anggaran Pendapatan dan Belanja Desa (APBDes) dan laporan Realisasi APBDes pemerintah desa Citanglar membatasinya sebagai bentuk kehati-hatian perangkat desa Citanglar dari pihak-pihak yang tidak bertanggungjawab dan menyalahgunakan data-data keuangan desa untuk hal-hal yang dapat merugikan Desa. Hal ini tentunya mengurangi prinsip Transparansi dalam pengelolaan Anggaran Pendapatan dan 
Belanja Desa (APBDes) di Desa Citanglar.

b. Transparansi Desa Jagamukti Pada saat pelaksanaan kegiatan pemberdayaan masyarakat yang didanai oleh Anggaran Pendapatan dan Belanja Desa (APBdes) perangkat Desa memasang papan program kegiatan berupa banner yang ada dilokasi pembangunan dan dikantor Desa juga dipasang Anggaran Pendapatan dan belanja Desa (APBDes) sehingga informasi mudah di akses oleh masyarakat untuk mengetahui jumlah anggaran yang digunakan disetiap program kegiatan pemberdayaan Masyarakat. Sehingga transparansi dalam kegiatan pengelolaan Anggaran Pendapatan dan Belanja Desa (APBDes) terjalankan.

c. Transparansi Desa Kademangan Bentuk transparansi yang dilakukan Desa Kademangan dalam Pengelolaan Anggaran Pendapatan dan Belanja Desa (APBDes) Desa Kademangan yaitu dengan melakukan musyawarah Dusun (Musdus) dan Musyawarah Desa (Musdes) yang dimana setiap masyarakat mengajukan program kegiatan yang dicatat dan ditampung untuk dijadikan program Anggaran Pendapatan dan belanja Desa (APBDes) Desa Kademangan. Selain itu juga perangkat desa mensosialisasikan setiap kegiatan yang didanai oleh Anggaran pendapatan dan Belanja Desa (APBDes) dalam kegiatankegiatan perkumpulan masyarakat desa, seperti maulid Nabi, isra Mi'raj ataupun kegiatan pengajian mingguan. Namun di Desa Kademangan Belum memasang papan Pengelolaan Anggaran Pendapatan dan Belanja Desa (APBDes) yang seharusnya di pasang di depan kantor Desa. Sehingga untuk Transparansi APBDes nya belum terlaksana dengan Baik.

\section{PENUTUP}

\section{SIMPULAN}

Berdasarkan hasil penelitian yang bertuang pada pembahasan, maka dapat ditarik kesimpulan akhir dari penelitian Penerapan Prinsip Akuntabilitas dan Transparansi dalam Pengelolaan Anggaran Pendapatan dan Belanja Desa (APBDes) di Desa Citanglar, Desa Jagamukti dan Desa Kademangan Kecamatan Surade Kabupaten Sukabumi adalah sebagai berikut:

1. Penerapan Akuntabilitas

Pengelolaan

Anggaran

Pendapatan dan Belanja Desa pada Desa Citanglar, Desa Jagamukti dan Desa Kademangan adalah sebagai berikut:

a. Akuntabilitas tahap perencanaan pengelolaan Anggaran Pendapatan dan Belanja Desa (APBDes) di Desa Citanglar, Desa Jagamukti dan Desa Kademangan pada penerapannya sudah sesuai dengan Peraturan Menteri dalam Negeri Nomor 113 Tahun 2014 tentang Pengelolaan Keuangan Desa. Hal ini dibuktikan dengan adanya Musyawarah Dusun (Musdus) dan Musyawarah Desa (Musdes) yang dilaksanakan untuk 
$\begin{array}{lr}\text { menampung } & \begin{array}{r}\text { aspirasi } \\ \text { dalam }\end{array} \\ \text { perencanaan } & \text { desa Pengelolaan }\end{array}$ Anggaran Pendapatan dan Belanja Desa (APBDes) namun masih kegiatan musyawarah dusun (Musdus) ini masih kurang efektif dikarenakan kurangnya sumber daya manusia dan juga kurangnya kesadaran masyarakat mengenai partisipasi dalam pengelolaan APBDes

b. Akuntabilitas tahap Pelaksanaan pengelolaan Anggaran Pendapatan dan Belanja Desa (APBDes) di Desa Citanglar, Desa Jagamukti dan Desa Kademangan pada penerapannya sesuai dengan Peraturan Menteri dalam Negeri Nomor 113 Tahun 2014 tentang Pengelolaan Keuangan. Hal ini dibuktikan dengan mekanisme pelaksanaan serta adanya rekening kas Desa.

c. Akuntabilitas tahap penatausahaan pengelolaan Anggaran Pendapatan dan Belanja Desa (APBDes) di Desa Citanglar, Desa jagamukti dan Desa Kademangan pada penerapannya telah sesuai dengan Peraturan Menteri dalam Negeri Nomor 113 Tahun 2014 tentang pengelolaan Keuangan Desa. Hal ini dibuktikan dengan adanya penggunaan Sistem Keuangan Desa untuk pengelolaan Keuangan Pemerintah Desa. Buku Kas Umum, Buku Pembantu Pajak, Laporan Realisasi APBDes. d. Tahap Pelaporan dan Pertanggungjawaban Realisasi APBDes di Desa Citanglar, Desa Jagamukti dan Desa Kademangan telah dilaksanakan sesuai dengan Peraturan Menteri dalam Negeri Nomor 113 Tahun 2014 tentang Pengelolaan Keuangan Desa. Yaitu ketiga desa telah melaporkan Realisasi Semester satu dan dua serta laporan Realisasi APBDes di akhir tahun angggaran.

2. Penerapan Transparansi Desa Citanglar, Desa Jagamukti dan Desa Kademangan untuk penerapannya masih kurang sesuai dengan Peraturan Menteri dalam Negeri Nomor 113 Tahun 2014 tentang Pengelolaan Keuangan Desa, karena meskipun sudah adanya papan pengumuman mengenai pengelolaan Anggaran Pendapatan dan Belanja Desa (APBDes). Akan tetapi untuk laporan realisasi Anggaran Pendapatan dan Belanja Desa tidak diinformasikan kepada masyarakat secara tertulis dan memberikan batasan kepada masyarakat, jadi tidak semua masyarakat dapat mengakses data terkait laporan realisasi APBDes. hal ini tentu mengurangi tingkat Transparansi di Desa Citanglar, Desa Jagamukti dan Desa Kademangan.

3. Faktor pendukung dan penghambat dalam penerapan prinsip Akuntabilitas dan Transparansi dalam Pengelolaan Anggaran Pendapatan dan belanja Desa pada Desa Citanglar, Desa Jagamukti dan Desa Kademangan 
yaitu adanya perangkat desa yang kompeten dalam melakukan pengelolaan Anggaran Pendapatan dan Belanja Desa sehingga prinsip Akuntabilitas dan Transparansi pengelolaan Keuangan Desa terjalankan. Sedangkan untuk hambatannya yaitu kurangnya sumberdaya manusia yang memiliki keinginan untuk ikut berpartisipasi dalam pengelolaan anggaran pendapatan dan belanja Desa.

\section{SARAN}

Dalam rangka meningkatkan kualitas pengelolaan keuangan desa yang berkualitas sehingga mewujudkan prinsip Akuntabilitas dan Transparansi, maka peneliti memberikan beberapa saran atau rekomendasi berdasarkan hasil penelitian di Desa Citanglar, Desa Jagamukti dan Desa Kademangan Kecamatan Surade.

1. Untuk pemerintahan Desa yang sudah melaksanakan Prinsip akuntabilitas dan Transparansi dalam pengelolaan Keuangan Desa dengan baik semoga bisa dipertahankan dan bisa ditingkatkan lagi menjadi lebih baik lagi, sementara yang belum melaksanakan prinsip akuntabilitas dan transparansi dengan sesuai diharapkan untuk melaksanakannya karena akuntabilitas dan transparansi pengelolaan Keuangan Desa adalah salah bentuk pengimplementasian Peraturan Menteri dalam Negeri Nomor 113 Tahun 2014 tentang Pengelolaan Keuangan.

2. Untuk peneliti selanjutnya diharapkan dapat menambahkan indikator-indikator yang relevan untuk mengukur tingkat
Akuntabilitas dan Transparansi Pengelolaan Anggaran Pendapatan dan Belanja Desa (APBDes)

\section{DAFTAR PUSTAKA}

Efra. 2017. Akuntabilitas Pemerintah Desa dalam Pengelolaan Anggaran Pendapatan dan Belanja Desa (APBDes) tahun 2015 Berdasarkan Permendagri No. 113 Tahun 2014. Vol.4 No. 3.

http://kupang.tribunnews.com/2016/0 4/08/masalah-pengelolaankeuangan-desa.(27 Maret 2019).

Iqsan. 2016. Transparansi Pemerintah Desa dalam Penyususnan Anggaran Pendapatan dan Belanja Desa (APBDes). Vol. 4 No. 1.

Lina dan Nuranisa. 2017. Akuntabilitas Pengelolaam Keuangan Desa. Vol. 10 No. 2.

Peraturan Menteri Dalam Negeri Republik Indonesia Nomor 113 Tahun $2014 \quad$ Tentang Pengelolaan Keuangan Desa.

Peraturan Pemerintah Nomor 71 Tahun 2010 Tentang Standar Akuntansi Pemerintah.

Soleh, Chabib dan Rochmansjah, Heru. 2015. Pengelolaam Keuangan Desa. Jatinangor: Fokus Media.

Sugiyono. 2017. Metode Penelitian Kuantitatif, Kualitatif dan R \& D. Bandung: Alfabeta.

Sujarweni wiratna. 2015. Akuntansi Desa Panduan Tata Kelola Keuangan Desa. Yogyakarta : Pustaka Baru Press Yogyakarta 
Nani Anggriani, dkk

Undang-undang Nomor 6 Tahun 2014

Tentang Pengelolaan Keuangan

Desa . 